\title{
ANALISIS KINERJA KEUANGAN PERBANKAN PT BANK TABUNGAN NEGARA (PERSERO) TBK PADA PERIODE TAHUN $2017-2019$
}

\author{
Fajar Fauzan Kemal ${ }^{1}$, Ikman Noor Fiqri ${ }^{2}$, Inayah Maryam Maajid ${ }^{3}$, Dila Afriyani ${ }^{4}$, Muhamad \\ Dzikri Abdurohman ${ }^{5}$, Muhammad Iqbal Ramdhani' \\ 1,2,3,4,5,6 Universitas Islam Negeri Sunan Gunung Djati Bandung \\ Email :Dzikrim45@gmail.com
}

\begin{abstract}
Abstrak
Penelitian ini berjudul Analisis Laporan Keuangan Menggunakan Metode Rasio Keuangan Untuk Menilai Kesehatan Perbankan Bank Tabungan Negara (Persero) Tbk pada periode 2017 - 2019. Penelitian ini bertujuan untuk menganalisis kinerja perusahaan melalui metode rasio keuangan. Jenis data yang digunakan dalam penelitian ini yaitu data sekunder yang bersumber dari annual report PT Bank Tabungan Negara (Persero) Tbk dari tahun 2017 sampai dengan 2019 serta data pedukung lainnya. Dari hasil penelitian didapatkan bahwa hasil rasio keuangan menunjukan kinerja yang sangat baik dari tahun 2017 sampai dengan 2019 dan berdasarkan dari kriteria Bank Indonesia kinerja keuangan dapat dikategorikan dalam kategori sehat.
\end{abstract}

Kata Kunci : Rasio Keuangan, Tingkat Kesehatan Perbankan

\begin{abstract}
This study is entitled Financial Statement Analysis Using the Financial Ratio Method to Assess the Banking Health of Bank Tabungan Negara (Persero) Tbk in the period 2017 - 2019. This study aims to analyze the company's performance through the financial ratio method. The type of data used in this study is secondary data sourced from the annual report of PT Bank Tabungan Negara (Persero) Tbk from 2017 to 2019 as well as other supporting data. From the results of the studyit was found that the results of financial ratios showed very good performance from 2017 to 2019 and based on Bank Indonesia criteria financial performance can be categorized in the healthy category.
\end{abstract}

Keyword : Financial Ratios, Banking Soundnes

\section{A. PENDAHULUAN}

Pada masa Orde Baru, Lembaga Keuangan diatur dengan dikeluarkannya Surat Keputusan Menteri Keuangan Republik Indonesia No. 792 Tahun 1990 tentang Lembaga Keuangan, menjelaskan bahwa Lembaga keuangan merupakan semua badan yang kegiatannya di bidang keuangan, melakukan penghimpunan dan penyaluran dana kepada masyarakat terutama dalam membiayai investasi pembangunan. Artinya, pada masa itu Lembaga keuangan diprioritaskan untuk melakukan pembangunan. Pada era reformasi, Surat keputusan ini mengalami perubahan dengan dikelluarkannya Undang-Undang RI Nomor 10 tahun 1998 dan menyatakan 
bahwa, Lembaga keuangan adalah badan usaha yang menghimpun dana dari masyarakat dalam bentuk simpanan dan menyalurkannya kepada masyarakat dalam bentuk kredit dan atau bentuk-bentuk lainnya dalam rangka meningkatkan taraf hidup rakyat banyak.

Di Indonesia sendiri, Lembaga Keuangan terdiri dari lembaga keuangan bank dan lembaga keuangan bukan bank. Semua lembaga keuangan ini berada di bawah naungan OJK (Otoritas Jasa Keuangan) yang mana sebelumnya berada di bawah naungan BI (Bank Indonesia). Secara umum, bank memiliki fungsi dalam menghimpun dana dari masyarakat luas (funding) dan menyalurkan dalam bentuk pinjaman atau kredit (lending) untuk berbagai tujuan. Dilihat perannya yang sangat penting, maka pemerintah perlu memastikan bahwa bank harus dalam keadaan sehat sehingga bagi masyarakat yang menyimpan dananya akan merasa aman dan bank sendiri juga berada pada kondisi yang siap untuk memberikan pinjaman ataupun melakukan jasa lainnya. Selain itu dengan kondisi yang sehat, bank dapat menunjang perekonomian Indonesia lebih baik (Haryanto dan Hanna, 2012).

Secara sederhana tingkat kesehatan bank dapat dikatakan bahwa bank yang sehat adalah bank yang dapat menjalankan fungsi-fungsinya dengan baik. Dengan menjalankan fungsi-fungsi tersebut diharapkan dapat memberikan pelayanan yang baik kepada masyarakat serta bermanfaat bagi perekonomian secara keseluruhan. Untuk mengetahui kondisi ini, kita perlu melakukan analisis terhadap kinerja keuangannya terlebih dahulu. Analisis kesehatan pada bank sendiri memiliki beberapa metode, salah satunya menggunakan analisis Rasio Keuangan Bank.

Dalam metode analisis Rasio Keuangan Bank, laporan keuangan merupakan alat yang menjadi tolok ukurnya, sehingga setiap perusahaan yang go public terutama bank wajib untuk mempublikasikannya Indikator yang dapat kita lihat menggunakan analisis rasio ini diantaranya adalah rasio likuiditas yang menilai kemampuan perusahaan dalam memenuhi kewajiban jangka pendeknya, rasio rentabilitas untuk menilai kemampuan perusahaan dalam menghasilkan laba, rasio risiko usaha bank yang melihat dan menilai risiko yang dihadapi dalam menjalankan usaha, sedangkan untuk rasio permodalan menilai perusahaan dalam mengukur modal untuk menutupi kerugian, dan yang terakhir yaitu rasio efisiensi usaha untuk mengukur tingkat efisiensi perusahaan, sehingga dari seluruh rasio yang digunakan kita dapat mengetahui seberapa sehat perusahaan tersebut.

\section{B. TUJUAN PENELITIAN}

Tujuan penelitian ini adalah untuk mengetahui dan menganalisis kinerja keuangan pada PT Bank 
Tabungan Negara (Persero) pada periode 2017-2019 dengan menggunakan metode Analisi Rasio Keuangan Bank

\section{LANDASAN TEORI}

Analisis rasio keuangan merupakan suatu teknik analisis untuk mengetahui hubungan dari pospos dalam laporan posisi keuangan dan laporan laba rugi secara individu atau kombinasi antara kedua laporan tersebut. Analisis rasio keuangan digunakan sebagai alat untuk menganalisa laporan keuangan dalam menilai kondisi keuangan perusahaan. Rasio keuangan menggambarkan suatu hubungan antara jumlah tertentu dengan jumlah lainnya. Dengan alat rasio ini akan dapat menjelaskan atau memberikan gambaran kepada penganalisa tentang baik atau buruknya posisi keuangan suatu perusahaan serta bertujuan untuk melihat sampai seberapa jauh ketepatan kebijakan manajemen dalam mengolah keuangan perusahaan dalam setiap tahunnya.

Menurut Darmawi (2011: 201) Analisis perbandingan (ratio analysis) merupakan suatu teknik atau peralatan untuk mengevaluasi kondisi financial dan kinerja sebuah organisasi perusahaan.

Sedangkan menurut Abdullah (2005: 123), nalisis ratio keuangan merupakan teknik analisis keuangan untuk mengetahui hubungan di antara pos-pos tertentu dalam neraca maupun laporan laba rugi baik secara individu maupun secara simultan.

Berdasarkan pengertian di atas dapat disimpulkan bahwa analisis rasio keuangan adalah suatu analisis yang menggambarkan hubungan dua data keuangan atau lebih antara yang satu dengan yang lainnya. Analisis rasio keuangan berguna untuk menentukan kesehatan keuangan suatu perusahaan baik pada saat sekarang maupun masa datang. Dengan rasio keuangan kondisi keuangan dan kinerja perusahaan untuk suatu periode tertentu dapat diungkapan serta diketahui kekuatan dan kelemahan perusahaan dalam bidang keuangan.

\section{Jenis Rasio Keuangan}

Jenis rasio keuangan yang digunakan dalam menganalisis perubahan tingkat rasio keuangan PT. Bank Tabungan Negara (Persero) Tbk. Adalah sebagai berikut :

A. Rasio Likuiditas adalah rasio yang menggambarkan kemampuan perusahaan untuk menyelesaikan kewajiban jangka pendeknya. Sedangkan untuk perbankan rasio likuiditas digunakan untuk mengetahui kemampuan bank untuk memenuhi seluruh kewajiban hutang- 
hutangnya dan dapat membayar kembali kepada semua deposannya serta dapat memenuhi permintaan kredit yang diajukan tanpa terjadi penangguhan. Berikut ini perhitungan pada rasio likuiditas yang digunakan :

a. Quick Ratio (mengukur kemampuan bank dalam memenuhi kewajibannya pada para deposan yaitu pemilik giro, tabungan dan deposito dengan harta yang paling likuid). Quick ratio ini dapat dihitung dengan :

\section{Cash Asset \\ Quick Ratio $=\longrightarrow$ 100\% \\ Total Deposit}

b. Cash Ratio ( mengukur kemampuan perusahaan dalam membayar kewajiban finansial jangka pendek dengan mengunakan kas yang tersedia dan berikut surat berharga atau efek jangka pendek). Cash Ratio ini dapat dihitung dengan :

$$
\text { Cash Ratio }=\text { Kas }+ \text { Efek } \quad x 100 \%
$$

\section{Pinjaman yang harus segera dibayar}

c. Loan to Deposit Rasio (mengukur komposisi kredit yang diberikan dibandingkan dengan jumlah dana masyarakat dan modal sendiri). ini dapat dihitung dengan :

$$
L D R=\frac{\text { Total Loans }}{\text { Total Deposit }} \times 100 \%
$$

d. Asset to Loan Ratio (mengukur jumlah kredit yang disalurkan dengan harta yang dimiliki bank). ini dapat dihitung dengan :

$$
A L R=\frac{\text { Total Loans }}{\text { Total Asset }} x 100 \%
$$


B. Rasio Solvabilitas, rasio ini digunakan untuk mengukur kemampuan bank dalam mencari sumber dana untuk membiayai kegiatan bank atau alat ukur untuk melihat kekayaan bank serta melihat efisiensi pihak manajemen bank. Berikut perhitungan rasio solvabilitas yang digunakan :

a. Primary Ratio (mengukur permodalan yang dimiliki bank telah memadai atau sejauh mana penurunan yang terjadi dalam total asset masuk dapat ditutupi oleh capital equity). ini dapat dihitung dengan :

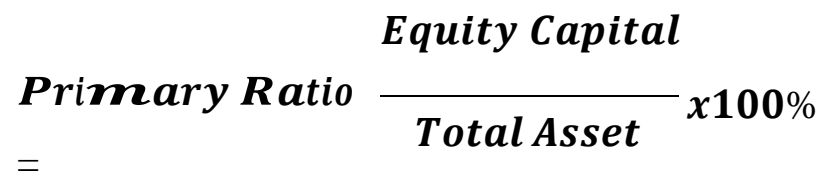

b. Risk Asset Ratio (mengukur kemungkinan penurunan risk asset). ini dapat dihitung dengan :

$R A R=\frac{\text { Equity Capital }}{\text { Total Asset-Cash Asset-Securities }} \times 100 \%$

c. Capital Ratio (mengukur permodalan dan cadangan penghapusan dalam menanggung perkreditan, terutama resiko yang terjadi karena ada kegagalan dalam menagih bunga bank). ini dapat dihitung dengan:

\section{Equity Capital + \\ Capital Ratio $=\underline{\text { Reserve for Loan Losses }} x 100 \%$ \\ Total Loans}

C. Rasio Profitabilitas Rasio ini digunakan untuk mengukur tingkat efisiensi usaha dan profitabilitas yang dicapai oleh bank. Berikut perhitungan rasio profitabilitas yang digunakan :

a. Gross Profit Margin (mengukur presentasi laba dari kegiatan usaha murni bank setelah dikurangi biaya-biaya). ini dapat dihitung dengan : 


\section{Operating Income - Operating}

Expense $\quad x 100 \%$

$\boldsymbol{G P M}=$

\section{Operating Income}

b. Net Profit Margin (mengukur kemampuan bank dalam menghasilkan net income dari kegiatan operasi pokok bank). ini dapat dihitung dengan :

$$
\text { NPM }=\quad \text { Net Income }
$$

Operating Income $e^{x 100 \%}$

c. Return Equity Capital atau (ROE) ( mengukur kemampuan manajemen bank dalam mengelola capital yang ada untuk mendapatkan net income). ini dapat dihitung dengan :

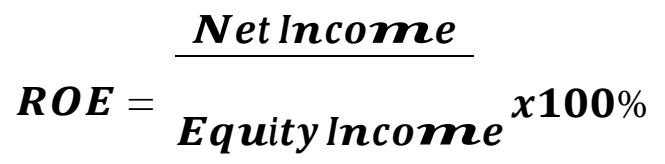

d. Return on Asset Ratio (ROA), (rasio untuk mengukur Tingkat pengembalian aset merupakan rasio profitabilitas untuk menilai persentase keuntungan (laba) yang diperoleh perusahaan terkait sumber daya atau total aset sehingga efisiensi suatu perusahaan dalam mengelola asetnya bisa terlihat dari persentase rasio ini). ini dapat dihitung dengan :

\section{Laba Bersih}

$$
\text { ROA= Total Aset } \quad x \text { 100\% }
$$

\section{Metode}

PT Bank Tabungan Negara (Persero) Tbk. pada periode 2017-2019 dipilih untuk dilakukannya penelitian dalam Praktik Kerja Lapangan Online (PKLO) ini. Objek penelitian yang dilakukan adalah Laporan Keuangan PT Bank Tabungan Negara (Persero) Tbk. periode 2017-2019 yang diperoleh dari situs www.btn.co.id.

Jenis penelitian yang digunakan adalah deskriptif kuantitatif. Titik utama penelitian ini adalah menentukan tingkat kesehatan PT Bank Tabungan Negara (Persero) Tbk. dengan melakukan penilaian terhadap rasio keuangan yaitu rasio likuiditas dan rasio solvabilitas dan faktor-faktor RGEC yang terdiri dari Risk Profile (risiko), Good Corporate Governance, Earning (rentabilitas), dan Capital 
ARTIKEL

(permodalan). Analisis yang dilakukan dalam penelitian ini berdasarkan pokok-pokok ketentuan tingkat kesehatan bank yang tertuang pada Peraturan Bank Indonesia (PBI) No. 13/01/PBI/2011 dan Surat Edaran Bank Indonesia (SEBI) No. 13/24/DPNP tanggal 25 Oktober 2011.

\section{E. HASIL DAN PEMBAHASAN}

\section{A. Menghitung Rasio Likuiditas pada PT. Bank Tabungan Negara (Persero) Tbk. Periode 2017-2019}

Rasio likuiditas menganalisa perbandingan harta lancer yang dimiliki perusahaan dengan hutang atau kewajiban lancar yang harus segera dipenuhi oleh perusahaan. Rasio ini menghitung pospos yang ada pada laporan keuangan yang bersifat jangka pendek. Dalam menghitung tingkat likuiditas yang dimiliki Bank BTN penulis menggunakan quick ratio, cash asset, loan to deposite ratio, dan loan to asset ratio berikut ini merupakan perolehan perhitungan yang di dapat penulis :

\section{a. Quick Ratio}

Untuk menghitung Quick Ratio penulis menggunakan rumus sebagai berikut :

\section{Cash Asset}

Quick Ratio = $x \mathbf{1 0 0} \%$

\section{Total Deposit}

Keterangan :

Cash Aset $\quad$ : Kas, Giro pada Bank Indonesia, Giro pada Bank Lain, Penempatan pada Bank Indonesia dan Bank Lain, Efek-efek, Obligasi Pemerintah.

Total Deposit : Liabilitas Segera, Simpanan dari Nasabah, Simpanan dari Bank Lain.

Tabel 1. 1 Quick Ratio

Bank Tabungan Negara Periode 2017-2019

(dalam jutaan rupiah)

\begin{tabular}{|c|c|c|c|}
\hline Tahun & Cash Asset & Total Deposit & Quick Ratio (\%) \\
\hline $\mathbf{2 0 1 7}$ & Rp. 54.725.947 & Rp. 184.968.728 & $29,58 \%$ \\
\hline $\mathbf{2 0 1 8}$ & Rp. 59.954.911 & Rp. 216.328.997 & $27,71 \%$ \\
\hline $\mathbf{2 0 1 9}$ & Rp. 47.864.830 & Rp. 213.414.113 & $22,42 \%$ \\
\hline
\end{tabular}

Hasil perhitungan Quick Ratio diatas dapat dihitung pertahun sebagai berikut : 
1) Quick Ratio tahun $2017=\frac{\operatorname{Rp} .54 .725 .947}{x 100 \%}$

$$
\text { Rp.184.968.728 }
$$

$=29,58 \%$

Quick ratio mengukur kemampuan Bank Tabungan Negara (BTN) dalam memenuhi kewajiban finansial jangka pendek yang berupa total deposit dengan menggunakan aktiva lancar yang lebih likuid. Atau dengan kata lain merupakan perimbangan atara aktiva lancar dengan hutang lancar. Quick ratio Bank BTN per 31 Desember 2017 sebesar 29,58\%

2) Quick Ratio tahun $2018=\frac{\mathrm{Rp} .59 .954 .911}{100 \%}$

$$
\text { Rp.216.328.997 }
$$

$$
=27,71 \%
$$

Quick ratio mengukur kemampuan Bank Tabungan Negara (BTN) dalam memenuhi kewajiban finansial jangka pendek yang berupa total deposit dengan menggunakan aktiva lancar yang lebih likuid. Atau dengan kata lain merupakan perimbangan atara aktiva lancar dengan hutang lancar. Quick ratio Bank BTN per 31 Desember 2018 sebesar 27,71\%.

3) Quick Ratio tahun $2019=\operatorname{Rp.47.864.830} \times 100 \%$

$$
\text { Rp.213.414.113 }
$$

$=22,42 \%$

Quick ratio mengukur kemampuan Bank Tabungan Negara (BTN) dalam memenuhi kewajiban finansial jangka pendek yang berupa total deposit dengan menggunakan aktiva lancar yang lebih likuid. Atau dengan kata lain merupakan perimbangan atara aktiva lancar dengan hutang lancar. Quick ratio Bank BTN per 31 Desember 2019 sebesar 22,42\%.

\section{b. Cash Ratio}

Untuk menghitung Cash Ratio penulis menggunakan rumus sebagai berikut : Keterangan : 


\section{Current Asset}

$$
\text { Cash Ratio }=\frac{}{\text { Current Liabilities }} \times 100 \%
$$

Current Asset : Kas, Efek, Obligasi Pemerintah

Current Liabilities : Liabilitas segera, Simpanan nasabah, Simpanan dari Bank lain

Tabel 1. 2 Cash Ratio

Bank Tabungan Negara Periode 2017-2019

(dalam jutaan rupiah)

\begin{tabular}{|c|c|c|c|}
\hline Tahun & Current Asset & Current Liabilities & Cash Rastio (\%) \\
\hline $\mathbf{2 0 1 7}$ & Rp. 16.917.558 & Rp. 184.968.728 & $9,14 \%$ \\
\hline $\mathbf{2 0 1 8}$ & Rp. 16.485.238 & Rp. 216.328.997 & $7,62 \%$ \\
\hline $\mathbf{2 0 1 9}$ & RP. 20.507.439 & Rp. 213.414.113 & $9,60 \%$ \\
\hline
\end{tabular}

Hasil perhitungan Cash Ratio diatas dapat dihitung pertahun sebagai berikut :

1) Cash Ratio tahun $2017=\frac{\mathrm{Rp} \cdot 16.917 .558}{100 \%}$

$$
\text { Rp.184.968.728 }
$$

$$
=9,14 \%
$$

Cash ratio merupakan alat ukur pada rasio likuiditas yang mengukur kemampuan perusahaan dalam membayar kewajiban jangka pendek dengan menggunakan kas, efek dan surat berharga yang tersedia. Cash ratio Bank BTN per 31 Desember 2017 sebesar 9,14\%.

2) Cash Ratio tahun $2018={ }^{\mathrm{Rp} .16 .485 .238} \times 100 \%$

$$
\text { Rp.216.328.997 }
$$

$=7,62 \%$

Cash ratio merupakan alat ukur pada rasio likuiditas yang mengukur kemampuan perusahaan dalam membayar kewajiban jangka pendek dengan menggunakan kas, efek dan surat berharga yang tersedia. Cash ratio Bank BTN per 31 Desember 2018 sebesar 7,62\%. 
3) Cash Ratio tahun $2019=\frac{\text { RP.20.507.439 }}{x 100 \%}$

$$
\text { Rp.213.414.113 }
$$

$=9,60 \%$

Cash ratio merupakan alat ukur pada rasio likuiditas yang mengukur kemampuan perusahaan dalam membayar kewajiban jangka pendek dengan menggunakan kas, efek dan surat berharga yang tersedia. Cash ratio Bank BTN per 31 Desember 2017 sebesar 9,60\%.

c. Loan to Deposit Ratio (LDR)

Untuk menghitung Loan to Deposit Ratio (LDR) penulis menggunakan rumus sebagai berikut :

Keterangan :

Total Loans $x 100 \%$

\section{LDR= Total Deposit}

Total Loans : Kredit yang Diberikan dan Pembiayaan/Piutang Syariah

Total Deposit : Liabilitas Segera, Simpanan dari Nasabah, Simpanan dari Bank Lain.

Tabel 1. 3 Loan to Deposit Ratio (LDR)

Bank Tabungan Negara Periode 2017-2019

(dalam jutaan rupiah)

\begin{tabular}{|c|c|c|c|}
\hline Tahun & Total Loans & Total Deposit & $\begin{array}{c}\text { Loan to Deposit Ratio } \\
(\boldsymbol{\%})\end{array}$ \\
\hline $\mathbf{2 0 1 7}$ & Rp. 196.634 .594 & Rp. 184.968 .728 & $106.30 \%$ \\
\hline $\mathbf{2 0 1 8}$ & Rp. 234.999 .600 & Rp. 216.328 .997 & $108.63 \%$ \\
\hline $\mathbf{2 0 1 9}$ & Rp. 249.708 .993 & Rp. 213.414 .113 & $117,00 \%$ \\
\hline
\end{tabular}

Hasil perhitungan Loan to Deposit Ratio diatas dapat dihitung pertahjun sebagai berikut :

1) $L D R$ tahun $2017=$ Rp.196.634.594 $x 100 \%$

Rp.184.968.728

$$
=106.30 \%
$$


ARTIKEL

loan to deposite ratio merupakan pengukuran antara besarnya seluruh volume kredit yang disalurkan oleh bank dengan jumlah penerimaan dana dari berbagai sumber untuk memenuhi permohonan pinjaman nasabahnya. Loan to deposite ratio pada Bank BTN per 31 Desember 2017 sebesar $106,30 \%$.

2) $L D R$ tahun $2018={ }^{\mathrm{Rp} .234 .999 .600} \times 100 \%$

$$
\text { Rp.216.328.997 }
$$

$$
=108.63 \%
$$

loan to deposite ratio merupakan pengukuran antara besarnya seluruh volume kredit yang disalurkan oleh bank dengan jumlah penerimaan dana dari berbagai sumber untuk memenuhi permohonan pinjaman nasabahnya. Loan to deposite ratio pada Bank BTN per 31 Desember 2018 sebesar $108,63 \%$.

3) $L D R$ tahun $2019={ }^{\mathrm{Rp} .249 .708 .993} \times 100 \%$

$$
\text { Rp.213.414.113 }
$$

$=117,00 \%$

loan to deposite ratio merupakan pengukuran antara besarnya seluruh volume kredit yang disalurkan oleh bank dengan jumlah penerimaan dana dari berbagai sumber untuk memenuhi permohonan pinjaman nasabahnya. Loan to deposite ratio pada Bank BTN per 31 Desember 2019 sebesar $117,00 \%$.

\section{d. Loan ti Asset Ratio (LAR)}

Untuk menghitung Loan ti Asset Ratio (LAR) penulis menggunakan rumus sebagai berikut :

Total Loans

$$
A L R=\overline{\text { Total Asset }} x 100 \%
$$

Keterangan :

Total Loans : Kredit yang Diberikan dan Pembiayaan / Piutang Syariah

Total Asset : Total Asset

Tabel 1. 4 Loan to Asset Ratio (LAR)

Bank Tabungan Negara Periode 2017-2019 
ARTIKEL

(dalam jutaan rupiah)

\begin{tabular}{|c|c|c|c|}
\hline Tahun & Total Loans & Total Asset & Loan ti Asset Ratio (LAR) (\%) \\
\hline $\mathbf{2 0 1 7}$ & Rp. 196.634.594 & Rp. 261.365.267 & $75,23 \%$ \\
\hline $\mathbf{2 0 1 8}$ & Rp. 234.999.600 & Rp. 306.436.194 & $76,68 \%$ \\
\hline $\mathbf{2 0 1 9}$ & Rp. 249.708.993 & Rp. 311.776.828 & $80,09 \%$ \\
\hline
\end{tabular}

Hasil perhitungan Loan to Asset Ratio diatas dapat dihitung pertahun sebagai berikut :

1) $L A R$ tahun $2017=\underline{\operatorname{Rp} .196 .634 .594} \times 100 \%$

$$
\text { Rp.261.365.267 }
$$

$$
=75,23 \%
$$

Loan to asset ratio merupakan perhitungan dalam analisis rasio likuiditas dengan mengukur kemampuan bank dalam memenuhi permintaan kredit dengan menggunakan total asset yang dimiliki oleh bank. Pada Bank BTN per 31 Desember 2017 adalah sebesar 75,23\%.

2) $L A R$ tahun $2018={ }^{\mathrm{Rp} .234 .999 .600} \times 100 \%$

$$
\begin{aligned}
& \text { Rp.306.436.194 } \\
= & \mathbf{7 6 , 6 8 \%} \%
\end{aligned}
$$

Loan to asset ratio merupakan perhitungan dalam analisis rasio likuiditas dengan mengukur kemampuan bank dalam memenuhi permintaan kredit dengan menggunakan total asset yang dimiliki oleh bank. Pada Bank BTN per 31 Desember 2018 adalah sebesar 76,68\%.

3) $L A R$ tahun $2019={ }^{\mathrm{Rp} .249 .708 .993} \times 100 \%$

$$
\begin{aligned}
& \text { Rp.311.776.828 } \\
= & \mathbf{8 0 , 0 9 \%} \%
\end{aligned}
$$

Loan to asset ratio merupakan perhitungan dalam analisis rasio likuiditas dengan mengukur kemampuan bank dalam memenuhi permintaan kredit dengan menggunakan total asset yang dimiliki oleh bank. Pada Bank BTN per 31 Desember 2017 adalah sebesar 80,09\%.

\section{A. Menghitung Rasio Solvabilitas pada PT. Bank Tabungan Negara (Persero) Tbk. Periode 2017-2019}

Rasio solvabilitas menggambarkan kemampuan bank dalam membayar atau memenuhi 
ARTIKEL

kewajiban jangka panjang atau pada saat perusahaan mengalami likuidasi. Pos - pos yang dapat dihitung untuk mengukur rasio ini yang bersifat jangka panjang seperti aktiva tetap dan hutang jangka panjang seperti aktiva tetap dan hutang jangka panjang. Perhitungan yang digunakan untuk melihat tingkat solvabilitas berdasar primary ratio, risk asset ratio, capital ratio dan berikut ini perhitungan yang didapat penulis :

\section{Primary Ratio}

Untuk menghitung Primary Ratio penulis menggunakan rumus sebagai berikut :

\begin{tabular}{|c|c|c|c|}
\hline & & Equity Capit & \\
\hline & Primary Ratio & Total Asset & $x 100 \%$ \\
\hline Keterangan : & $=$ & & \\
\hline Equity Capital & : Jumlah Ekuitas & & \\
\hline Total Asset & : Jumlah Aset & & \\
\hline
\end{tabular}

Tabel 1. 5 Primary Ratio

Bank Tabungan Negara Periode 2017-2019

(dalam jutaan rupiah)

\begin{tabular}{|c|c|c|c|}
\hline Tahun & Equity Capital & Total Asset & Primary Ratio (\%) \\
\hline $\mathbf{2 0 1 7}$ & Rp. 21.663.434 & Rp. 261.365 .267 & $0,82 \%$ \\
\hline $\mathbf{2 0 1 8}$ & Rp. 23.840 .448 & Rp. 306.436.194 & $0,77 \%$ \\
\hline $\mathbf{2 0 1 9}$ & Rp. 23.836.195 & Rp. 311.776.828 & $0,76 \%$ \\
\hline
\end{tabular}

Hasil perhitungan Primary Ratio diatas dapat dihitung pertahun sebagai berikut :

1) Primary Ratio tahun $2017=\mathrm{Rp}^{21.663 .434} \times 100 \%$

Rp.261.365.267

$$
=\mathbf{0 , 8 2 \%}
$$


Primary ratio digunakan untuk mengukur permodalan yang dimiliki bank telah memadai atau sejau mana penurunan yang terjadi dalam total asset masuk dapat ditutupi oleh capital equity. Pada Bank BTN per 31 Desember 2017 adalah sebesar 0,82\%.

2) Primary Ratio tahun $2018=$ Rp.23.840.448 $x 100 \%$

$$
\text { Rp.306.436.194 }
$$

$$
=\mathbf{0 , 7 7 \%}
$$

Primary ratio digunakan untuk mengukur permodalan yang dimiliki bank telah memadai atau sejau mana penurunan yang terjadi dalam total asset masuk dapat ditutupi oleh capital equity. Pada Bank BTN per 31 Desember 2018 adalah sebesar 0,77\%.

3) Primary Ratio tahun $2019=\mathrm{Rp} \cdot 23.836 .195 \times 100 \%$

$$
\text { Rp.311.776.828 }
$$

$$
=0,76 \%
$$

Primary ratio digunakan untuk mengukur permodalan yang dimiliki bank telah memadai atau sejau mana penurunan yang terjadi dalam total asset masuk dapat ditutupi oleh capital equity. Pada Bank BTN per 31 Desember 2019 adalah sebesar 0,76\%.

\section{Risk Asset Ratio (RAR)}

Untuk menghitung Risk Asset Ratio (RAR) penulis menggunakan rumus sebagai berikut :

Equity Capital

Keterangan : $\quad \boldsymbol{R A R}=$ Total Asset - Cash Asset - Securities $x 100 \%$

$$
\text { Equity Capital : Jumlah Ekuitas }
$$

Total Asset - Cash Asset - Securities : total asset, kas, Giro pada Bank Indonesia, Giro pada Bank Lain, Penempatan pada Bank Indonesia dan Bank Lain, Efek-efek, Obligasi Pemerintah

\section{Tabel 1. 6 Risk Asset Ratio (RAR)}

Bank Tabungan Negara Periode 2017-2019

(dalam jutaan rupiah)

\begin{tabular}{|l|l|l|l|}
\hline Tahun & Equity Capital & Total Asset - Cash & Risk Asset Ratio \\
\hline
\end{tabular}


ARTIKEL

\begin{tabular}{|c|c|c|c|c|}
\hline & & Asset - Securities & (RAR) (\%) \\
\hline $\mathbf{2 0 1 7}$ & Rp. 21.663 .434 & Rp. 206.639.320 & $10,48 \%$ \\
\hline $\mathbf{2 0 1 8}$ & Rp. 23.840.448 & Rp. 246.481.283 & $9,67 \%$ \\
\hline $\mathbf{2 0 1 9}$ & Rp. 23.836.195 & Rp. 263.911.998 & $9,03 \%$ \\
\hline
\end{tabular}

Hasil perhitungan Cash Ratio diatas dapat dihitung pertahun sebagai berikut :

1) $R A R$ tahun $2017={ }^{\mathrm{Rp} \cdot 21 \cdot 663.434} x 100 \%$

Rp.206.639.320

\section{$=10,48 \%$}

risk asset ratio digunakan untuk mengukur kemampuan bank dalam kemungkinan penurunan risiko asset. Risk asset ratio pada Bank BTN per 31 Desember 2017 sebesar 10,48\%.

2) $R$ AR tahun $2017={ }^{\mathrm{Rp} .23 .840 .448} \times 100 \%$

$$
\text { Rp.246.481.283 }
$$

$=9,67 \%$

risk asset ratio digunakan untuk mengukur kemampuan bank dalam kemungkinan penurunan risiko asset. Risk asset ratio pada Bank BTN per 31 Desember 2018 sebesar 9,67\%.

3) $R A R$ tahun $2017=\mathrm{Rp}^{\mathrm{R} \cdot 23.836 .195} \times 100 \%$

$$
\text { Rp.263.911.998 }
$$

$$
=\mathbf{9 , 0 3 \%}
$$

risk asset ratio digunakan untuk mengukur kemampuan bank dalam kemungkinan penurunan risiko asset. Risk asset ratio pada Bank BTN per 31 Desember 2019 sebesar 9,03\%.

1) Capital Ratio tahun $2017=21.663 .434 \times 100 \%$

$$
196.634 .594
$$

$$
=11,01 \%
$$

Capital ratio digunakan untuk mengukur permodalan dalam bentuk ekuitas dengan cadangan penghapusan dalam menanggung risiko perkreditan dengan menggunakan total loans, terutama risiko yang terjadi karena bunga gagal ditagih.capital ratio Bank BTN per 31 Desember 2017 sebesar $11,01 \%$. 
2) Capital Ratio tahun $2018=23 \frac{.840 .448}{x} \times 100 \%$

234.999.600

$=10,14 \%$

Capital ratio digunakan untuk mengukur permodalan dalam bentuk ekuitas dengan cadangan penghapusan dalam menanggung risiko perkreditan dengan menggunakan total loans, terutama risiko yang terjadi karena bunga gagal ditagih.capital ratio Bank BTN per 31 Desember 2018 sebesar $10,14 \%$.

3) Capital Ratio tahun $2019=\frac{23.836 .195}{100 \%}$

249.708.993

$=\mathbf{9 , 5 4 \%}$

Capital ratio digunakan untuk mengukur permodalan dalam bentuk ekuitas dengan cadangan penghapusan dalam menanggung risiko perkreditan dengan menggunakan total loans, terutama risiko yang terjadi karena bunga gagal ditagih.capital ratio Bank BTN per 31 Desember 2019 sebesar $9,54 \%$.

Menghitung faktor-faktor RGEC (Risk Profile, Good Corporate Governance, Earning, dan Capital) pada PT. Bank Tabungan Negara (Persero) Tbk. Periode 2017-2019

\section{(1) Risk Profile (Profil Resiko)}

a. Resiko kredit diukur dengan rasio NPL (Non-Performing Loan)

Kesehatan PT Bank Tabungan Negara (Persero) Tbk. berdasarkan rasio NPL

\begin{tabular}{|c|c|c|c|}
\hline Tahun & Nilai & Peringkat & Predikat \\
\hline 2017 & $2,66 \%$ & 2 & Sehat \\
\hline 2018 & $2,81 \%$ & 2 & Sehat \\
\hline 2019 & $4,78 \%$ & 2 & Sehat \\
\hline
\end{tabular}

Sumber: Data diolah, 2020 
Nilai rasio NPL yang semakin kecil menunjukkan bahwa bank semakin baik dan tepat dalam memberikan kredit, sehingga kredit yang tergolong kurang dan tidak lancar berkurang. Nilai NPL Bank BTN selama tahun 2017-2019 adalah 2,66\%, 2,81\%, dan 4,78\%. Nilai tersebut menunjukkan bahwa kualitas kredit Bank BTN memiliki predikat sehat. Namun, nilai NPL Bank BTN dari tahun 2017-2019 mengalami penurunan dan penurunan yang signifikan terlihat pada tahun 2019. Hal ini menunjukkan bahwa progres majaemen dalam mengelola kolektabilitas dan menjaga kualitas kredit mengalami tren penurunan walaupun secara rata-rata nilai NPL Bank BTN masih dalam keadaan sehat, yaitu 3,39\%.

b. Resiko likuiditas diukur dengan rasio LDR (Loan to Deposit Ratio)

Kesehatan PT Bank Tabungan Negara (Persero) Tbk. berdasarkan rasio LDR

\begin{tabular}{|c|c|c|c|}
\hline Tahun & Nilai & Peringkat & Predikat \\
\hline 2017 & $103,13 \%$ & 4 & Kurang Sehat \\
\hline 2018 & $103,49 \%$ & 4 & Kurang Sehat \\
\hline 2019 & $113,50 \%$ & 5 & Tidak Sehat \\
\hline
\end{tabular}

Sumber: Data diolah, 2020

Nilai LDR Bank BTN pada tahun 2017-2019 adalah 103,13\%, 103,49\%, dan 113,50\%. Hal ini menunjukkan bahwa perusahaan memiliki masalah likuiditas sehingga meningkatkan resiko yang dihadapi. Tabel di atas menunjukkan bahwa pada tahun 2017 dan 2018, Bank BTN memiliki predikat likuiditas yang kurang sehat. Pada tahun 2019 predikat tersebut semakin menurun pada level terendah, Bank BTN memiliki predikat likuiditas yang tidak sehat pada tahun 2019 berdasarkan rasio LDR.

\section{(2) Good Corporate Governance (GCG)}

Kesehatan PT Bank Tabungan Negara (Persero) Tbk. berdasarkan Nilai GCG / Self Assessment

\begin{tabular}{|c|c|c|c|}
\hline Tahun & Nilai & Peringkat & Predikat \\
\hline 2017 & 2 & 2 & Sehat \\
\hline 2018 & 2 & 2 & Sehat \\
\hline 2019 & 2 & 2 & Sehat \\
\hline
\end{tabular}

Sumber: Data diolah, 2020

Nilai GCG Bank BTN tahun 2017-2019 meunjukkan nilai rata-rata 2. Hal ini meunjukkan bahwa manajemen Bank BTN tidak mengalami permasalahan dalam mengelola governance perusahaan. 


\section{(3)Earnings (Rentabilitas)}

a. ROA (Return on Assets)

Kesehatan PT Bank Tabungan Negara (Persero) Tbk. berdasarkan Nilai ROA

\begin{tabular}{|c|c|c|c|}
\hline Tahun & Nilai & Peringkat & Predikat \\
\hline 2017 & $1,71 \%$ & 1 & Sangat Sehat \\
\hline 2018 & $1,34 \%$ & 2 & Sehat \\
\hline 2019 & $0,13 \%$ & 4 & Kurang Sehat \\
\hline
\end{tabular}

Sumber: Data diolah, 2020

Data tersebut menampilkan bahwa Bank BTN pada tahun 2017-2019 memiliki nilai ROA 1,71\%, $1,34 \%$, dan 0,13\%. Nilai ini menyatakan bahwa nilai ROA Bank BTN mengalami tren penurunan yang signifikan. Dengan penurunan ini, Bank BTN mengalami penurunan predikat dari predikat sangat sehat pada tahun 2017 sampai pada predikat kurang sehat di tahun 2019 pada nilai return on assets-nya.

b. NIM (Net Interest Margin)

Kesehatan PT Bank Tabungan Negara (Persero) Tbk. berdasarkan Nilai NIM

\begin{tabular}{|c|c|c|c|}
\hline Tahun & Nilai & Peringkat & Predikat \\
\hline 2017 & $4,76 \%$ & 1 & Sangat Sehat \\
\hline 2018 & $4,32 \%$ & 1 & Sangat Sehat \\
\hline 2019 & $3,32 \%$ & 1 & Sangat Sehat \\
\hline
\end{tabular}

Sumber: Data diolah, 2020

Data di atas menunjukkan nilai NIM Bank BTN pada tahun 2017-2019 adalah 4,76\%, 4,32\%, dan 3,32\%. Dari data tersebut dapat disimpulkan bahwa nilai NIM Bank BTN mengalami fluktuasi, tetapi tidak memberikan dampak yang signifikan sehingga menunjukan kemampuan perusahaan untuk memperoleh pendapatan bunga bersih tetap berada pada predikat sangat sehat walaupun mengalami tren penurunan.

c. BOPO (Biaya Operasional terhadap Pendapatan Operasional)

Kesehatan PT Bank Tabungan Negara (Persero) Tbk. berdasarkan Nilai BOPO

\begin{tabular}{|c|c|c|c|}
\hline Tahun & Nilai & Peringkat & Predikat \\
\hline 2017 & $82,06 \%$ & 1 & Sangat Sehat \\
\hline 2018 & $85,58 \%$ & 3 & Cukup Sehat \\
\hline 2019 & $98,12 \%$ & 5 & Tidak Sehat \\
\hline
\end{tabular}


Sumber: Data diolah, 2020

Data tersebut menunjukkan bahwa nilai BOPO Bank BTN mengalami tren penurunan yang signifikan pada tahun 2017-2019, yaitu 82,06\%, 85,58\%, sampai 98,12\%. Nilai ini menyatakan bahwa Bank BTN mengalami peningkatan beban operasional dan memiliki permasalah dalam pendapatan operasional. Penurunan nilai BOPO ini membawa Bank BTN berpindah dari predikat sangat sehat pada predikat tidak sehat selama tiga tahun terakhir.

\section{(4)Capital Adequacy Ratio (Rasio Kecukupan Modal - CAR)}

Kesehatan PT Bank Tabungan Negara (Persero) Tbk. berdasarkan Nilai CAR

\begin{tabular}{|c|c|c|c|}
\hline Tahun & Nilai & Peringkat & Predikat \\
\hline 2017 & $18,87 \%$ & 1 & Sangat Sehat \\
\hline 2018 & $18,21 \%$ & 1 & Sangat Sehat \\
\hline 2019 & $17,32 \%$ & 1 & Sangat Sehat \\
\hline
\end{tabular}

Sumber: Data diolah, 2020

Data di atas menunjukkan tingkat kesehatan Bank BTN dari aspek kecukupan modal (CAR) memiliki predikat sangat sehat pada tahun 2017-2019, yaitu 18,87\%, 18,21\%, dan 17,32\%. Hal ini menyatakan bahwa bank dapat memenuhui kewajiban jika terjadi kerugian operasional dan dapat mendukung penyaluran kredit.

\section{F. KESIMPULAN}

Tabel 1. 8 Tabulasi Rasio Likuiditas

Bank Tabungan Negara Periode 2017-2019

\begin{tabular}{|l|l|c|c|c|c|c|}
\hline \multirow{2}{*}{ No. } & \multirow{2}{*}{ Aspek } & \multicolumn{3}{|c|}{ Tahun } & \multicolumn{2}{c|}{ Keterangan Naik/Turun } \\
\cline { 3 - 7 } & & $\mathbf{2 0 1 7}$ & $\mathbf{2 0 1 8}$ & $\mathbf{2 0 1 9}$ & $\mathbf{2 0 1 7 - 2 0 1 8}$ & $\mathbf{2 0 1 8 - 2 0 1 9}$ \\
\hline 1. & Quick Ratio & $29,58 \%$ & $27,71 \%$ & $22,42 \%$ & $(-) 1,87 \%$ & $(-) 5,29 \%$ \\
\hline 2. & Cash Ratio & $9,14 \%$ & $7,62 \%$ & $9,60 \%$ & $(-) 1,52 \%$ & $(+) 1,98 \%$ \\
\hline 3. & $\begin{array}{l}\text { Loan to Deposit } \\
\text { Ratio (LDR) }\end{array}$ & $106.30 \%$ & $108.63 \%$ & $117,00 \%$ & $(+) 2,33 \%$ & (+) $8,37 \%$ \\
\hline 4. & $\begin{array}{l}\text { Loan to Asset } \\
\text { Ratio (LAR) }\end{array}$ & $75,23 \%$ & $76,68 \%$ & $80,09 \%$ & $(+) 1,45 \%$ & (+) $3,41 \%$ \\
\hline
\end{tabular}


Berdasarkan table 1.8 mengenai Tabulasi Rasio Likuiditas diatas, PT. Bank Tabungan Negara (Persero) Tbk. Selama periode tahun 2017 sampai dengan tahun 2019 mengalami perubahan diberbagai aspek perhitungan mulai dari quick ratio sampai dengan loan to asset ratio baik itu perubahan kearah positif atau bahkan kearah negatif. Hal ini bisa kita pada quick ratio tahun 20172018 mengalami penurunan sebesar (-) 1,87\% dan pada tahun 2018-2019 mengalami penurunan kembali sebesar (-) 5,29\%. Walaupun nilai dari quick ratio ini mengalami penurunan secara konsisten namun masih berada pada angka yang masih relatif baik, karena bank BTN masih mampu memenuhi kewajiban jangka pendek dengan harta yang paling likuid.

Untuk cash ratio pada tahun 2017-2018 memang mengalami penurunan namun masih pada angka yang relative kecil yaitu sebesar (-)1,52\%. Dan pada tahun 2019 rasio cash ratio mengalami kenaikan dan lebih besar dari tahun 2017 yakni sebesar 9,60\% meningkat 1,98\% lebih besar dari tahun 2018 sebesar 7,62\%. Angka cash rasio ini masih berada pada angka positif berada di atas 3\% dari ketentuan, yang berarti bahwa ban BTN masih mampu membayar kewajiban finansial jangka pendek dengan menggunakan kas yang tersedia dan berikut dengan berbagai surat berharga jangka pendek.

Sedangkan pada loan to deposit ratio setiap tahun mengalami perkembangan yang cukup baik, bisa diliat dari kenaikan mulai dari 2017 - 2019 yakni sebesar 106.30\%, 108.63\%, 117,00\%. Hal ini tentunya berdampak baik bagi bank karena dengan semakin besarnya persentasi loan to deposite setiap kredit yang diberikan mengalami peningkatan juga dengan kepercayaan yang diberikan masyarakat dan modal sendiri yang dimiliki bank BTN. Untuk loan to asset ratio pun bergerak satu arah sama dengan LDR yang pada tahun 2017-2019 pun sama mengalami kenaikan yakni sebesar (+) 1,45\% pada 2017 - 2018 dan (+) 3,41\% pada tahun 2018 - 2019. Hal ini juga dapat kita juga dengan peningkatan total loans dan total deposite.

Secara keseluruhan untuk rasio likuiditas PT. Bank Tabungan Negara (Persero) Tbk. Periode 2017- 2019 berada pada angka atau persentasi yang masih baik walaupun ada beberapa rasio yang bergerak kearah negative namun tidak mengakibatkan minat penyimpan dana menurun. Hal ini juga tentunya karena fungsi dan kegiatan bank itu sendiri yaitu sebagai penarik dan penyalur dana kepada masyarakat, khususnya di Bank BTN ini pada perkreditan rumah. 
Tabel 1. 9 Tabulasi Rasio Solvabilitas

Bank Tabungan Negara Periode 2017-2019

\begin{tabular}{|c|c|c|c|c|c|c|}
\hline \multirow{2}{*}{ No. } & \multirow{2}{*}{ Aspek } & \multicolumn{3}{|c|}{ Tahun } & \multicolumn{2}{|c|}{ Keterangan Naik/Turun } \\
\hline & & 2017 & 2018 & 2019 & 2017-2018 & 2018-2019 \\
\hline 1. & $\begin{array}{l}\text { Primary } \\
\text { Ratio }\end{array}$ & $0,82 \%$ & $0,77 \%$ & $0,76 \%$ & (-) $0,05 \%$ & (-) $0,01 \%$ \\
\hline 2. & $\begin{array}{l}\text { Risk Asset } \\
\text { Ratio }\end{array}$ & $10,48 \%$ & $9,67 \%$ & $9,03 \%$ & (-) $0,81 \%$ & (-) $0,64 \%$ \\
\hline 3. & $\begin{array}{l}\text { Capital } \\
\text { Ratio }\end{array}$ & $11,01 \%$ & $10,14 \%$ & $9,54 \%$ & (-) $0,87 \%$ & (-) $0,60 \%$ \\
\hline
\end{tabular}

Pada tabulasi rasio solvabilitas diatas, secara keseluruhan bisa dikatakan kurang baik karena setiap perhitungan rasio dan setiap tahun mengalami penurunan secara konsisten. Bisa kita lihat pada primary ratio pada tahun 2017 sebesar 0,82\% sdan menurun sebesar (-) 0,05\% pada tahun 2018 menjadi 0,77\% dan turun lagi pada tahun 2019 menjadi 0,76\%. Walaupun mengalami penurunan pada 3 tahun tersebut modal yang dimiliki perbankan masih memadai dan belum bernilai negatif sehingga total asset yang dimiliki masih dapat ditutupi oleh jumlah ekuitas yang dimiliki.

Pada risk asset ratio juga masih bergerak turun setiap tahun sejak tahun 2017 - 2019. Namun, bank masih dapat meneruskan usahanya atau bahkan memperluas usahanya sesuai dengan tugasnya menambah pinjaman yang akan diberikan atau penyaluran kredit dan giro atau hal lainnya karena masih jauh dari angka negative. Yang berarti bahwa bank masih dapat menurunkan risiko pada asset yang dimilikinya. Sedangkan pada capital ratio walaupun juga mengalami penurunan setiap tahun namun angkanya masih berada diatas ketentuan standar Bank Indonesia yakni diatas 8\% Capital Adenquicy Ratio. Yang berarti bahwa modal yang dimiliki oleh bank dan cadangan cadangan penghapusan dalam menanggung risiko terutama risiko yang terjadi karena kegagalan dalam menagih bunga bank masih dapat ditutupi oleh bank. Dengan hal tersebut diatas artinya bank dapat mengatasi risiko kerugian yang dialami oleh bank, misalnya pada kredit macet. Jadi dengan perhitungan atau rasio solvabilitas bank akan menunjukan keadaan keuangan yang baik.

Hasil penilaian Profil Resiko (Risk Profile) Bank BTN dengan nilai NPL Bank BTN selama 
tahun 2017-2019 adalah 2,66\%, 2,81\%, dan 4,78\% yang berarti bank memiliki predikat sehat. Serta Nilai LDR Bank BTN pada tahun 2017-2018 secara berturut-turut adalah 103,13\%, 103,49\%, dan $113,50 \%$ yang berarti dalam predikat kurang sehat. Hasil penilaian faktor Good Corporate Governance (GCG) Bank BTN selama tahun 2017-2019 didapatkan nilai 2, 2, dan 2 yang berarti dalam aspek ini bank memiliki predikat sehat.

Hasil penilaian rentabilitas (earnings) Bank BTN dengan menggunakan tiga jenis rasio yaitu ROA, NIM, dan BOPO pada tahun 2017-2019, bank berada pada kategori cukup sehat. Hal ini ditunjukkan dengan nilai ROA Bank BTN tahun 2017-2019 berturut-turut adalah 1,71\%, 1,34\%, dan 0,13\% yang berarti cukup sehat. Nilai NIM Bank BTN tahun 2017-2019 berturut-turut adalah 4,76\%, 4,32\%, dan 3,32\% yang berarti sangat sehat. Serta nilai BOPO Bank BTN pada tahun 2017-2019 yaitu $82,06 \%$, 85,58\%, dan 98,12\% yang berarti kurang sehat. Hasil penilaian aspek permodalan (capital) Bank BTN pada tahun 2017-2019 berada dalam kondisi sangat sehat, yaitu dengan ditunjukan nilai CAR Bank BTN selama tiga tahun tersebut adalah 18,87\%, 18,21\%, dan 17,32\%.

Dari hasil penilaian seluruh faktor RGEC (Risk Profile, Good Corporate Governance, Earning, dan Capital) di atas, maka diperoleh hasil bahwa PT Bank Tabungan Negara (Persero) Tbk. pada tahun 2017-2019 secara umum merupakan bank yang sehat. Dalam beberapa indikator menunjukkan bahwa Bank BTN mendapatkan predikat bank yang sehat. Namun dalam beberapa indikator lain, Bank BTN dalam tiga tahun terakhir mengalami tren penurunan bahkan sampai pada predikat tidak sehat. Hal ini tentu karena berbagai persoalan yang dihadapi di tengah usaha dan progress pelaksanaan faktor-faktor yang dinilai tersebut sudah sesuai dengan ketetapan dan ketentuan Bank Indonesia serta berjalan dengan efektif dan efisien.

\section{DAFTAR PUSTAKA}

Bank Indonesia. (2012). Kodifikasi Peraturan Bank Indonesia Kelembagaan Penilaian Tingkat Kesehatan Bank. Retrieved from www.bi.go.id

Mulyawan, S. (2015). Manajemen Keuangan. Bandung: Pustaka Setia.

Febrina, R., Dwiatmanto, D., \& NP, M. (2016). Analisis Tingkat Kesehatan Bank Umum Berdasarkan Risk Profile, Good Corporate Governance, Earning, dan Capital (Studi pada Bank Umum yang Terdaftar di Bursa Efek Indonesia Periode 2013-2015). Jurnal Administrasi Bisnis S1 Universitas Brawijaya, 37(1).

A. Kinerja, K. Bank, T. Negara, and S. M. Jambi, "Iqra Wiarta; Endah Tri Kurniasih,” pp. 27-28, 2017.

A. A. Parathon, Dzulkirom, and D. Farah, "Analisis rasio keuangan perbankan sebagai alat ukur kinerja keuangan bank," Student e-journal UB, vol. 3, no. 2, pp. 1-11, 2012, [Online]. 
Available: administrasibisnis.studentjournal.ub.ac.id/index.php/jab/article/view/133\%0A.

A. Salsabila, "Pengertian Laporan keuangan,Tujuan Laporan Keuangan dan Analisis Laporan Keuangan,” J. Akunt., vol. 53, no. 9, pp. 1689-1699, 2015.

G. Memenuhi, S. Satu, S. Untuk, and G. S. Ekonomi, "Nama: Donny Rahdian Habibie NIM Departemen : Akuntansi Guna Memenuhi Salah Satu Syarat Untuk Memperoleh Gelar Sarjana Ekonomi," 2009.

M. L. Syafitri, “Analisis Rasio Solvabilitas dan Aktivitas pada PT. Bank Negara Indonesia,” 2017.

Bank Tabungan Negara (BTN). 2017. Laporan Tahunan. www.btn.co.id

Bank Tabungan Negara (BTN). 2018. Laporan Tahunan. www.btn.co.id

Bank Tabungan Negara (BTN). 2019. Laporan Tahunan. www.btn.co.id

Jurusan Manajemen FISIP UIN Sunan Gunung Djati Bandung. (2020). Pedoman Praktik Kerja Lapangan Online.

U. Keluarga and M. Indonesia, "Untuk keluarga milenial indonesia,” 2019. (Annual Report Bank BTN Tahun 2019).

Peraturan Bank Indonesia No. 13/01/PBI/2011

Surat Edaran Bank Indonesia No. 6/23/DPNP tanggal 31 Mei 2004

Surat Edaran Bank Indonesia No. 13/24/DPNP tanggal 25 Oktober 2011 